DOI: 10.33766/2524-0323.92.54-62

УДК 342.72/.73

\author{
Slovska I., \\ Full Phd in Law, Docent, \\ Professor at the Constitutional Law and \\ Branch Disciplines Department National \\ University National University of Water \\ and Environmental Engineering \\ (Rivne, Ukraine) \\ e-mail:slovska@ukr.net \\ iDhttps:// orcid.org/0000-0001-9587-2300
}

\title{
EVOLUTION OF CONSTITUTIONAL AND LEGAL REGULATION OF HUMAN RIGHTS IN UKRAINE IN THE CONTEXT OF DEVELOPMENT OF POLITICAL SYSTEMS
}

The article examines the evolution of the constitutional and legal regulation of human rights in Ukraine in the context of the development of political systems - from the MarxistLeninist type to the free European one. It is emphasized that, despite the positivist position on the interpretation of human rights, the ideologues of the modern state interpret it and law, as well as other social phenomena, through the prism of new idealistic concepts. In their opinion, the legal act synthesizes the state will, which is reflected in the legal norm and is obligatory for the competent body applying this norm. Subjective right of a person is interpreted as a measure of possible behavior, devoid of class features.

It is emphasized that the Constitution of Ukraine declares the highest social value of a person for his life and health, honor and dignity, inviolability and security. It is stressed that the establishment and protection of human rights and freedoms is the main duty of the state. Thus, according to the constitutional norms, the state is not a passive observer of the realization of the rights and freedoms of citizens, but an active participant in their protection.

The existence of state control over the observance and protection of individual rights and freedoms (activities of the state apparatus in the field of protection of rights) and public (control over the redistribution of social space between the state and civil society, coverage of problems between the state and citizens; control over the responsibility of the constitutional state before civil society) is examined. Emphasis is placed on the unity between state and public control over the implementation of social tasks, the effectiveness of social policy and, consequently, the effective protection of the rights, freedoms and legitimate interests of the individual.

It is stressed that the shortcomings of law enforcement practice, insufficient protection of individual rights by the state arise for a number of objective reasons. The annual reports of the Verkhovna Rada of Ukraine Commissioner for Human Rights on the observance and protection of the human rights and freedoms of citizens of Ukraine are based on these phenomena. The documents show shortcomings in the protection of all categories of rights and freedoms by public authorities.

The author emphasizes that an important factor in the effective functioning of the rule of law is the filling of state-power relations with real legal mechanisms. Real protection of human rights and freedoms is possible if all levels of public power are involved in improving the constitutional order. The number of reforms should be combined with their quality content. 
Keywords: human rights and freedoms, state, legal protection, state and public control, political system, law enforcement.

Formulation of the problem. A comprehensive analysis of social relations, taken in their historical development, reveals the causal objectively existing organic connection between the rights of the individual and the state. The state as a category of superstructure plan can be interpreted scientifically correctly only if it is considered in combination with the structure of society, which, in turn, is determined by the level of development and the nature of productive forces, the mode of production. Disclosure of the essence of individual rights, substantiation of objective regularities of replacement of some of these class-type opportunities by the capabilities of a new format with a natural humanistic character due to the formation of civil society in Ukraine - this is the general task of modern domestic constitutionalism.

Analysis of recent publications. In writing this article the author used scientific developments of such authors as: S. Bobrovnyk, V. Goshovska, A. Zayets, N. Onishchenko, N. Parkhomenko, O. Skrypnyuk, S. Chorna, S. Shevchuk, Y. Shemshuchenko and others.

Formulation of goals. The purpose of the proposed manuscript is to study the evolution of the constitutional and legal regulation of human rights in Ukraine in the context of the development of political systems - from the Marxist-Leninist type to the free European.

Presenting main material. The scientific theory we have inherited from Soviet times considers the legal nature of fundamental human rights exclusively from a positivist standpoint. As is well known, the positivist theory in law, the founders of which are rightly considered to be the English scholars D. Austin and J. Bentham, is based on three main postulates:

1. Separation of law from morality. According to the representatives of this theory, jurisprudence cannot engage in ethical analysis of positive law, because natural law does not meet clear criteria and is applied under the influence of personal moral convictions of the judge, ie is a substitute for the law's own moral judgments.

2. Law is always the expression or embodiment of human will - the order of the sovereign, which one person gives to another. Sovereign here means a person or state body that has the highest political power in society (king or people represented by parliament). And this order can have not only imperative, but also descriptive and general (ie to concern all) character. Interestingly, in this regard, the famous Nazi theorist of law K. Schmitt has repeatedly stated that decisions in disputes over the competence of state bodies should be made by the sovereign (the sole leader of the nation - the president), as there are no grounds for litigation.

3. Every current legal norm must be promulgated by the «sovereign of the legal system», and its authority must derive from the authority of the sovereign.

The legal understanding of most modern Ukrainian lawyers is based on these notions of law. As the Ukrainian scholar A. Zayets, to whom the equally well-known constitutionalist S. Shevchuk joins, rightly remarks: «Narrow normative approach to the definition of law, based on the idea that the law - the rules of conduct set out in laws and regulations, established and provided by the coercive force of state power, still find their supporters» [1, p. 135; 2]. 
Of course, the ideologues of the modern state consider it and law, as well, as other social phenomena through the prism of new idealistic concepts. The legal act synthesizes the state will, which is reflected in the legal norm and is obligatory for the competent body that applies this norm. Later, the source of the content of the act of law enforcement is the will, which is enshrined in the applicable law, and the will, which is carried out by a competent state body or official to exercise the right [3, p. 41]. Instead, any subjective right is a set of options of conduct allowed from the standpoint of the law the authorized subject [4, p. 32]; the measure of possible behavior of the participant of legal relations provided by norms of law. In other words, it is a measure of conduct that belongs to the authorized person to meet his interests and needs and is provided by the relevant legal obligations of other (obligated) persons [5].

The Basic Law of Ukraine stipulates that the highest social value in Ukraine is a person, his life and health, honor and dignity, inviolability and security. According to the Constitution, the establishment and protection of human rights and freedoms is the main duty of the state. It follows from these provisions that the state is not a passive observer of the rights and freedoms of citizens, but, on the contrary, is an active participant in ensuring their implementation, ie protection [6, p. 151]. As for the concept of "protection», for example, S. Alekseev understood it as the state-coercive activity aimed at the implementation of «restorative» tasks - the restoration of the violated right, ensuring the fulfillment of legal obligations [7, p. 202].

Along with state control over the observance and protection of individual rights and freedoms, there is also public control. First of all, it is control over the redistribution of social space between the state and civil society, coverage of problems that arise between the state and citizens, and most importantly - control over the responsibility of the constitutional state to civil society. So, to some extent, it is «control over the controllers». Thus, we can trace the corresponding unity between the state and public control over the implementation of social tasks, the effectiveness of social policy, and hence the effective protection of the rights, freedoms and legitimate interests of citizens.

It should be noted that control in the broadest sense is a democratic institution, because democracy in the broadest sense is control over the exercise of public power in society. The practical slice of all types of control in democratic legal systems covers the functional ability to ensure the rights, freedoms and legitimate interests of the individual, and hence: the legitimacy of power, which effectively protects the honor, dignity and human rights. Proper protection of rights and freedoms means effective governance, because the government in a democratic society is interested in effective control, given that this is its legitimacy [8, p. 25].

The turning point in the change of constitutional and legal regulation of individual rights was the Declaration of State Sovereignty of Ukraine. The fundamental act defined the new status of Ukraine: proclaimed its state sovereignty as the supremacy, independence, completeness and indivisibility of the power of the Republic within its territory and independence and equality in foreign relations. Without the Declaration of State Sovereignty of Ukraine, which initiated the latest stage of the state-building process, the next steps on this path would be impossible. The document became the first and determining factor in the factual and legal establishment of a sovereign and independent Ukraine, the 
emergence of which was a natural result of all the previous development of the Ukrainian people. At a historical distance, a third of a century later, his epoch-making role in the modern state-building process is becoming more and more obvious and significant. Program principles and provisions, such as self-determination of the Ukrainian people, assertion of sovereignty, development of a democratic society, comprehensive provision of human rights and freedoms, achievement of economic and social welfare of society, its cultural and spiritual revival on national principles, formation of sovereign state power within the republic, building the constitutional state and the development of self-governing principles of the people, peace-loving foreign policy of Ukraine, etc. - had a huge impact on the choice of civilization and the transformation of Ukrainian society.

The Declaration became a political document which, by virtue of its influence on social transformations, had the significance of a constitutional act. By its nature, it was a revolutionary document, because it declared a radical change in worldview and value orientations of society and determined the ways of its development [9, p. 10].

Analysis of the practice of state-building shows that the first decade of Ukraine's independence under the influence of social and economic changes focused on the political content of individual rights and it was to some extent declarative. The new state on the political map of the world tried to systematize the theoretical development of constitutional regulation of rights and freedoms, to comprehensively consider the mechanism of their interaction, to form its own view on the reality of citizen participation in political life. At that time of historical development, the achievements of sovereign Ukraine should include an attempt to understand the specifics of the methods of constitutional regulation, methods and techniques of constitutional influence on the development of political relations. The provision that the principle of direct effect of the Basic Law has not only legal but also special political significance, correctly guided the parliament and other public authorities to introduce new opportunities for dialogue between the state and society.

December 10 - Human Rights Day. On this day in 1948, the United Nations General Assembly adopted the Declaration of Human Rights. This historical event was due to the fact that after the Second World War, humanity has matured into the need to legally enshrine the greatest values - life, equality and freedom of people. Later, the articles of the Declaration, after the adoption of a number of international agreements, acquired the status of international law and formed the basis of national legislation [10].

In Ukraine, as in other Soviet republics, there were significant problems with the observance of all types of rights. However, political rights were the most formal. In fact, they were most strongly influenced by state ideology and the logically constructed system of legislation that regulated them had no practical meaning.

The shortcomings of the legal regulation of human rights and freedoms at the dawn of independence are largely due to the novelty and complexity of the topic.

Today, despite relatively perfect constitutional and legal regulations, many rights and freedoms have no real protection. Thus, Russia's armed aggression has brought special urgency to the protection of the right to life, liberty and security of person, freedom from torture, and freedom of movement. As a result of the Russian armed aggression against Ukraine about 9,940 people were killed and about 23,455 were injured (according 
to the UN, beg. of 2017). These figures include, in particular, 298 passengers on flight MH17, including 80 children who were victims of the terrorist attack on July 17, 2014, when a Malaysia Airlines plane was shot down by the Russian military with Buk SAM, which was taken to the occupied territory of Donbass from the territory RF.

About 1,584,000 Crimean and Donbass residents were forced to flee their homes as internally displaced persons. The following remain occupied: the Autonomous Republic of Crimea $(26,081 \mathrm{~km})$, the city of Sevastopol $(864 \mathrm{~km})$, part of the Donetsk and Luhansk regions $(16,799 \mathrm{~km})$ - a total of $43,744 \mathrm{~km}$, which is $7.2 \%$ of the territory of Ukraine.

The economy of Donbass is completely destroyed. The equipment of many once powerful Ukrainian plants was exported to the territory of the Russian Federation. The situation with flooded mining mines threatens a powerful environmental catastrophe [11]. This situation has a negative impact on economic rights, as Donbass is of great importance for Ukraine's industrial production. By 2014, this region accounted for about a quarter of the country's exports and more than 15\% of capital investment (State Statistics Service of Ukraine, 2014). Donbass was a supplier of raw materials such as coal, steel and other industrial goods for production abroad. As of August 2014, industrial production in the Donetsk economic region - Donetsk and Luhansk oblasts - decreased by $60 \%$ and $85 \%$, respectively, due to power outages and destruction of transport infrastructure.

If we calculate the consequences of the conflict by calculating the annual difference in GDP per capita between Ukraine and its synthetic counterpart after the war, the results indicate that the GDP per capita lost due to the war in Donbass on average in 20132017 (now the figures are significantly higher) was 15.1\%: 5.23\% (\$ 460.26), 9.18\% (\$ 832.96), 19.63\% (\$1,823.78), 19, 80\% (\$1,893.38), 21.67\% (\$2,184.13) in 2013, 2014, 2015, 2016 and 2017.

The results of the regional analysis confirm the devastating impact of the war in Donbass. In particular, according to experts, the Donetsk gross regional product (GRP) fell by an average of $42 \%(\$ 4,294)$ due to the war. For Luhansk, the decline is even greater - here the average decrease in GRP per capita is 52\% (\$3,355) [12].

At the same time, there are long-standing problems with the protection of individual rights, for the solution of which only the Ukrainian authorities are responsible. Of particular note is the right to a fair trial, where the results expected by society are still lacking, and changes in the judiciary have only just begun. The key problem is the lack of fair justice and, consequently, the insecurity of all other human rights at the national level. The question of how to ensure the integrity of judges with numerous reforms of the judiciary remains open.

The rights of children need protection even more than the rights of adults. The state must do everything necessary for families to have proper economic conditions for raising children. In addition, children should not live in boarding schools, but be raised in families. Although there is another problem - often children are returned to disadvantaged families in which they do not have the proper conditions for growth and development, both physical and spiritual [10].

The annual reports of the Verkhovna Rada of Ukraine Commissioner for Human Rights on the observance and protection of the human rights and freedoms of citizens of 
Ukraine [13] shows shortcomings in the protection of all categories of rights and freedoms. Undoubtedly, an important factor in the effective functioning of any state is the filling of state-power relations with real mechanisms, including legal ones. In general, the reform of the state system, which began in the 1990s, is far from complete. According to statistics for the last 10-12 years, direct and indirect social losses, primarily due to the inefficiency of the management system in Ukraine, amount to about $\$ 400$ billion. Another evidence of the need to modernize the state can be Ukraine's place in world rankings: 143rd - according to indicators of public administration of the World Bank among 212 countries; 82nd place in the global competitiveness index; 120th place in terms of quality of state institutions among 133 countries; 146th - Transparency International Corruption Perceptions Index among 180 countries; 62nd place in terms of online services (ranking of UN member states) out of 190 countries [14, p. 29-30; 15, p. 14].

It is difficult to imagine that with such statistical indicators Ukraine will be able to do without improving not only the practice of law enforcement, but also the regulatory framework.

Conclusions. The Ukrainian people are building a new society that seeks to be democratic and legal. On the basis of scientific and technological progress, the efficiency of social production, strengthening and improvement of its technologies and, accordingly, the growth of material, cultural and spiritual standard of living is expected.

During the years of independence, significant progress has been made in regulating the legal status of induvidials, but there are significant gaps in economic and cultural construction. It is obvious that only due to the hard work of people, their initiative, talent and intelligence it is impossible to make up for lost financial and material and human resources. Real achievements are possible if all branches of public power are involved in improving the constitutional order. The number of reforms should be combined with their quality content. Only under such conditions is it possible to increase the benefits of our society and real protection of individual rights.

\section{Used sources:}

1. Заєць А. Правова держава в контексті новітнього українського досвіду. Киӥв : Парламентське видавництво, 1999. 248 с.

2. Шевчук С. Європейська конвенщія про захист прав людини та основних свобод: практика застосування та принципи тлумачення у контексті сучасного українського праворозуміння. Український портал практики Європейського суду з прав людини. 1999. № 2. URL: http:/ / eurocourt.in.ua/Article.asp?AIdx=416. (дата звернення: 01.12.2020)

3. Бобровнік С. В. Правозастосовні акти: природа, сутність та місце в системі законодавства. Правова держава. 2019. Вип. 30. С. 35-43.

4. Карнаух Б. Зловживання правом та його правові наслідки. Підприємництво, господарство і право. 2020. № 9. С. 31-36.

5. Ведєрніков Ю. А., Папірна А. В. Теорія держави п права : навчальний посібник. Київ : Знання, 2008. 333 c.

6. Чорна С. Сутність права громадян на соціальний захист. Підприємництво, господарсmbo i право. 2019. № 4. С. 151-156.

7. Алексеев С. С. Общая теория права : учебник. Москва : Изд-во Проспект, 2008. 412 с.

8. Онищенко Н. М. Контроль за забезпеченням прав людини: дихотомія впливу. Правова держава. 2020. Вип. 31. С. 24-28. 
9. Шемшученко Ю. С., Скрипнюк О. В. Декларація про державний суверенітет України: історичне значення і завдання для сучасності (до 30-річчя прийняття Декларації). Правова держава. 2020. Вип. 31. С. 3-14.

10. Штогрін І. Які права людини в Україні найбілыше потребують захисту? Padio Cвобода. 10.12.2016. URL: https:/ / www.radiosvoboda.org/. (дата звернення: 01.12.2020)

11. 10 фактів про збройну агресію Росії проти України. Міністерство закордонних справ. 09.12.2019. URL : https:// mfa.gov.ua/10-faktiv-pro-zbrojnu-agresiyu-rosiyi-proti-ukray ini. (дата звернення: 01.12.2020)

12. Блущ Ю., Валенте М. У що обходяться гібридні війни: приклад України. Геополітика. 30.07.2020. URL: https://voxukraine.org/uk/u-shho-obhodyatsya-gibridni-vijni-prikladukrayini/. (дата звернення: 01.12.2020)

13. Щорічна доповідь Уповноваженого Верховної Ради з прав людини про стан додержання та захисту прав і свобод людини і громадянина в Україні за 2019 рік. URL : https:/ / file:/ / C:/Users/Super/Desktop/zvit\%20za\%202019.pdf. (дата звернення: 01.12. 2020)

14. Гошовська В., Пашко Л. Реформування Української держави як виклик сьогоденн. Вісник Національної академії державного управління. 2011. Вип. 1. С. 14-22. URL: http:// nbuv. gov.ua/UJRN/Vnadu_2011_1_4. (дата звернення: 01.12.2020)

15. Пархоменко Н. М. Теоретичні та практичні аспекти правового регулювання в сучасній Україні. Правова держава. 2019. Вип. 30. С. $29-35$.

\section{References:}

1. Zayets, A. (1999) Pravova derzhava v konteksti novitnoho ukrayinskoho dosvidu. Kyiv : Parlamentske vydavnytstvo. [in Ukrainian].

2. Shevchuk, S. (1999) Yevropeyska konventsiya pro zakhyst prav lyudyny ta osnovnykh svobod: praktyka zastosuvannya ta pryntsypy. Ukrainskyi portal praktyky Yevropeiskoho sudu z prav liudyny. portal praktyky Yevropeiskoho sudu z prav liudyny-Ukrainian portal of the case law of the European Court of Human Rights, 2. URL : http://eurocourt.in.ua/Article.asp?AIdx=416. [in Ukrainian].

3. Bobrovnik, S. V. (2019) Pravozastosovni akty: pryroda, sutnist ta mistse v systemi zakonodavstva. Pravova derzhava - Constitutional state, issue 30, 35-43. [in Ukrainian].

4. Karnaukh, B. (2020) Zlovzhyvannya pravom ta yoho pravovi naslidky. Pidpryyemnytstvo, hospodarstvo i parvo - Entrepreneurship, economy and law, 9, 31-36. [in Ukrainian].

5. Vedyernikov, YU. A., Papirna, A.,V. (2008) Teoriya derzhavy i prava : navchalnyy posibnyk. Kyiv: Znannya. [in Ukrainian].

6. Chorna, S. (2019) Sutnist prava hromadyan na sotsialnyy zakhyst. Pidpryyemnytstoo, hospodarstvo i pravo - Entrepreneurship, economy and law, 4, 151-156. [in Ukrainian].

7. Alekseev, S. S. (2008) Obshchaya teoryya prava : uchebnyk. Moskva : Yzd-vo Prospekt. [in Russian].

8. Onyshchenko, N. M. (2020) Kontrol za zabezpechennyam prav lyudyny: dykhotomiya vplyvu. Pravova derzhava - Constitutional state, issue 31, 24-28. [in Ukrainian].

9. Shemshuchenko, YU. S., Skrypnyuk, O. V. (2020) Deklaratsiya pro derzhavnyy suverenitet Ukrayiny: istorychne znachennya i zavdannya dlya suchasnosti (do 30-richchya pryynyattya Deklaratsiyi). Pravova derzhava - Constitutional state, 31, 3-14. [in Ukrainian].

10. Shtohrin, I. (2016) Yaki prava lyudyny v Ukrayini naybilshe potrebuyut zakhystu? Radio Svoboda - Radio Liberty. 10.12.2016. N. p. URL: https:/ / www.radiosvoboda.org/. [in Ukrainian].

11.10 faktiv pro zbroynu ahresiyu Rosiyi proty Ukrayiny. Ministerstvo zakordonnykh sprav. 09.12.2019. N. p. URL : https://mfa.gov.ua/10-faktiv-pro-zbrojnu-agresiyu-rosiyi-protiukrayini. [in Ukrainian]. 
12. Blushch, YU., Valente, M. U. (2020) shcho obkhodyatsya hibrydni viyny: pryklad Ukrayiny. Heopolityka. 30.07.2020. N. p. URL : https://voxukraine.org/uk/u-shho-obho dyatsya-gibridni-vijni-priklad-ukrayini/. [in Ukrainian].

13. Shchorichna dopovid Upovnovazhenoho Verkhovnoyi Rady z prav lyudyny pro stan doderzhannya ta zakhystu prav i svobod lyudyny i hromadyanyna v Ukrayini za 2019 rik. (2019) N. p. URL: https:/ / file:/ / C:/Users/Super/Desktop/zvit\%20za\%202019.pdf. [in Ukrainian].

14. Hoshovska, V., Pashko, L. (2011) Reformuvannya Ukrayinskoyi derzhavy yak vyklyk sohodenn. Visnyk Natsionalnoyi akademiyi derzhavnoho upravlinnya - Bulletin of the National Academy of Public Administration, issue 1, 14-22. URL: http://nbuv.gov.ua/UJRN/Vnadu_2011_1_4. [in Ukrainian].

15. Parkhomenko, N. M. (2019)Teoretychni ta praktychni aspekty pravovoho rehulyuvannya v suchasniy Ukrayini. Pravova derzhava - Constitutional state, issue 30, 29-35. [in Ukrainian].

Стаття надійила до реколеї 02.12.2020

Словська I. Є., доктор юридичних наук, доцент, професор кафедри конституційного права та галузевих дисциплін Національного університету водного господарства та природокористування (м. Рівне, Україна)

\section{ЕВОЛЮЦЯ КОНСТИТУЦЙНО-ПРАВОВОГО РЕГУЛЮВАННЯ ПРАВ ЛЮДИНИ В УКРАЇНІ В КОНТЕКСТІ РОЗВИТКУ ПОЛІТИЧНИХ СИСТЕМ}

У статті досліджується еволюція конституційно-правового регулювання прав людини в Україні в контексті розвитку політичних систем - від марксистсько-ленінського типу до вільного європейського. Зауважується, що, попри позитивістську позищію тлумачення прав особи, ідеологи сучасної держави розглядають її та право, як й інші суспільні явища, через призму нових ідеалістичних конщепщій. На їхню думку, у правовому акті синтезується державна воля, яка відображена в правовій нормі і є обов'язковою для компетентного органу, що застосовує дану норму. Суб'єктивне право особи тлумачиться як міра можливої поведінки, позбавленої класових рис.

Зазначається, що Конституція України проголошує найвищими соціальними цінностями людину, iї життя та здоров'я, честь та гідність, недоторканість та безпеку, тому встановлення та захист прав і свобод людини є головним обов'язком держави. Отже, згідно 3 конституційними нормами, держава є не пасивним спостерігачем реалізації прав і свобод громадян, а активним учасником їх захисту.

Досліджується існування державного контролю за дотриманням та захистом індивідуальних прав і свобод (діяльність державного апарату у сфері захисту прав) та громадського (контроль за перерозподілом соціального простору між державою та громадянським суспілством, висвітлення проблем між державою та громадянами; контроль за відповідальністю конституційної держави перед громадянським суспільством). Акцент робиться на єдності державного та громадського контролю за виконанням соціальних завдань, ефективністю соціальної політики і, отже, ефективним захистом прав, свобод та законних інтересів особи. 
Акцентується увага на недоліках практики правозастосування, недостатньому захисті прав особи з боку держави через низку об' єктивних причин. Ці явища висвітлюють щорічні звіти Уповноваженого Верховної Ради України з прав людини про дотримання та захист прав і свобод людини й громадянина в Україні. Документи свідчать про недоліки в захисті всіх категорій прав і свобод державними органами.

Автор зауважує, що важливим фактором ефективного функціонування правової держави є наповнення відносин держави та влади реальними правовими механізмами. Реальні здобутки можливі в разі долучення до вдосконалення конституційного ладу всіх ланок публічної влади. Кількість реформ слід поєднувати з їх якісним наповненням.

Ключові слова: права і свободи особи, держава, правовий захист, державний і громадський контроль, політична система, правозастосування.

Словская И. Е., доктор юридических наук, доцент, профессор кафедры конституционного права и отраслевых дисциплин Национального университета водного хозяйства и природопользования

(г. Ровно, Украина)

\section{ЭВОЛЮЦИЯ КОНСТИТУЦИОННО-ПРАВОВОГО РЕГУЛИРОВАНИЯ ПРАВ ЧЕЛОВЕКА В УКРАИНЕ В КОНТЕКСТЕ РАЗВИТИЯ ПОЛИТИЧЕСКИХ СИСТЕМ}

В статье исследуется эволюция конституционно-правового регулирования прав человека в Украине в контексте развития политических систем - от марксистско-ленинского типа к свободному европейскому. Подчеркивается, что, несмотря на позитивистскую позицию толкования прав человека, идеологи современного государства рассматривают его и право, как и другие общественные явления, через призму новых идеалистических конщепщий. По их мнению, в правовом акте синтезируется государственная воля, которая отражена в правовой норме и является обязательной для компетентного органа, применяющего данную норму. Субъективное право лица толкуют как меру возможного поведения, лишенную классовых свойств.

Акцентируется внимание на недостатках практики правоприменения, недостаточной защите прав человека со стороны государства по ряду объективных причин.

Ключевые слова: права и свободы человека, государство, правовая защита, государственный и общественный контроль, политическая система, правоприменение. 